821.163.41.09 Кашанин, Милан

821.163.41.09 Радичевић, Бранко

https://doi.org/10.18485/msc.2017.46.2.ch17

Зорица П. ХАЏИЋ*

Оригинални научни рад

Универзитет у Новом Саду

Примљен: 25. 10. 2016.

Филозофски факултет

Прихваћен: 10. 02. 2017.

\title{
„ИЗМЕЂУ ОРЛА И ВУКА” - КАШАНИН О БРАНКУ РАДИЧЕВИЋУ**
}

Есеј Милана Кашанина „Између орла и вука” дочекан је, најпре, негодовањем књижевне критике. У раду се прате и објашњавају узроци оваквих критика, иницираних Кашаниновим тумачењем утицаја јуначке народне епике на поезију Бранка Радичевића. Рад прати и могућна изворишта Кашаниновог есеја, од критике Ђорђа Малетића па све до студија његових савременика. Кашанин

Кључне речи: есеј, рецепција, историја књижевности, Бранко Радичевић, Милан

Новембарски број часописа Кюижевност из 1953. године отворио је есеј Милана Кашанина „Између орла и вука” посвећен песнику „Туге и опомене”. Кашаниново писање привукло је пажњу читалачке публике, јер је огласило повратак прокаженог писца у српску књижевност. ${ }^{1}$ Узроци скрајнутости некадашњег директора Музеја кнеза Павла биле су и књиге Два века српског сликарства (1942) и Уметност и уметници (1943) штампане током Другог светског рата. Због ових књига Кашанин је своју поратну ситуацију поредио са случајем злосрећног Боре Станковића којем је својевремено била спочитавана сарадња у Београдским новинама. Аршини за мерење подобности писаца били су, и остали, двојаки - јасно је да Кашанин није био једини писац који је штампао књиге током рата, као што ни Станковић није био једини сарадник озлоглашених Београдских новина.

*zorica_hadzic@ff.uns.ac.rs

** Рад је настао као део научног пројекта 178005 чији је руководилац проф. др Горана Раичевић, а који финансира Министарство просвете, науке и технолошког развоја Републике Србије.

${ }^{1}$ Према библиографији Милана Кашанина (Удовички 1982: 259-296) овом есеју претходило је предавање „Наши градови и дворови у прошлости” објављено 1944. године. Међутим, тај податак није у потпуности прецизан јер се пренебрегава Кашанинова, истина анонимна, сарадња у Политици, у рубрици „Да ли знате?”.

Иначе, Кашанин је 1951. године покушао да понови издање књиге Два века српског сликарства, али га је Матица српска одбила (Ковачек 2005: 937). 
Било како било, есеј „Између орла и вука”, настао поводом обележавања стогодишњице смрти Бранка Радичевића, успео је да узнемири књижевну чаршију и изазове још једну буру у, и тако бурним, педесетим годинама XX века у српској књижевности. У први мах уследила је салва негодовања упућена на рачун повратничког есеја прокаженог Милана Кашанина. Другим речима, чини се да ниједан Кашанинов есеј није био толико чангризаво и селективно читан као овај о Бранку Радичевићу. Пажња мрзовољне критике нарочито се задржавала на местима тумачења односа Вука Караџића и Бранка Радичевића. Тај однос Кашанин је, већ на самом почетку есеја, маркирао, одлучно негиравши било какве сличности између ове двојице посленика српске књижевности:

Немају ништа заједничко та два човека. Караџић је горштак и самоук, човек огромне енергије и велике практичне памети, творац песничког оруђа, а не поезије, створен за животну рачуницу, а не за вишу математику - Караџић уопште није писац, већ књижевни државник. [...] Радичевић је варошанин и латинац, песник и у књижевности и у животу, младић светског васпитања и усправног држања (Кашанин 1953: 365).

Сјајно предочавајући и доводећи у везу књижевноисторијске чињенице, Кашанин је непогрешиво успео да саблазни књижевне пуританце, нарочито промишљањем о погубном утицају јуначке народне песме на танану лиру младог песника, што је уназадило Радичевићеву поезију. Овакво промишљање значајно се одразило на првобитну негативну оцену есеја „Између орла и вука", оличену у селективном читању и честој замени теза. Јасно је да су предратне и поратне пишчеве прилике имале у свему овоме значајног удела, мада се нетрпељивост критике испољавала најчешће под велом забринутости због покушаја детронизације Вука Караџића. (Не морамо посебно ни да напомињемо да је Вук Караџић по окончању Другог светског рата у својој свити имао велики број гласних следбеника и заштитника.) Есеј „Између орла и вука” првобитно је представљен као Кашанинов напад на реформатора језика, те су у фокус интересовања избили искључиво пасажи у којима се помињао Вук Караџић.

Први пример селективног читања била је критика Ђуре Гавеле, који је у Политици од 20. новембра 1953. године штампао памфлетски осврт на Кашанинов есеј под насловом „Стари 'злодјеј' из Тршића”. Гавелина критика била је, готово у целости, изграђена на навођењу и профанисању Кашанинових судова. Том приликом, аутор књижице Српска књижевна задруга под окупацијом је у својој „слободнијој парафрази” Кашанину спочитавао и оно што јесте и оно што није написао (Гавела 1979: 141-144). Острашћени Гавела бранећи Вука, а пренебрегавајући све што је тачно и добро речено о Бранку Радичевићу, закључио је да су Кашаниново перо водиле „пакосне утваре Милована Видаковића, Штипкаловића, Вујића, Светића, Малетића". Од те нагле, бурне и неаргументоване Гавелине реакције започео је својеврсни одијум на Кашанина. ${ }^{2}$

\footnotetext{
${ }^{2}$ Петар Џаџић се овако сећао тог времена: „Ово је атентат на Вука, а шамар народу - викао је покојни Ђуро Гавела, од очаја мало припит, показујући у Клубу књижевника 'Књижевност' са
} 
Остало је, међутим, незапажено да је Гавела брзо добио одговор на своју малициозну критику. Осврт на његов приказ објављен је у другом броју београдског листа Уметност и критика под насловом „Проблем оригиналног и национални патос (Између орла и вука)” (Глушчевић 1953: 1 [34]). Узимајући наслов Кашаниновог есеја за поднаслов свог текста, и тиме стављајући његово писање о Бранку у први план, Зоран Глушчевић је почео одбрану наизглед издалека, полазећи од Зорана Мишића и Оскара Давича и њихових ставова према универзализму и космополитизму у књижевности, како би дошао до централне теме - ,једног изванредног есеја" и Гавелиног (не)схватања реченог. ${ }^{3}$ Насупрот Гавелиним произвољностима и парафразирањима, Глушчевићева аргументација у одбрани Кашанинових идеја имала је тежину и оправданост. ${ }^{4}$ Овај усамљени глас одбране у време најжешћих напада на Кашанина, остао је недовољно запажен. ${ }^{5}$ Ту судбину није делио есеј „Између орла и вука” јер је Кашаниново размишљање о Бранку Радичевићу нагонило критичаре и књижевне историчаре да се одреде према ономе што је изрекао. Тако је, на пример, Драгиша Живковић 1957. године, стао уз Гавелу и, узгредно, у једној напомени своје књиге дао негативну оцену Кашаниновог есеја (Живковић 1957: 204). ${ }^{6}$

Морамо да напоменемо да је било и усмених, врло жустрих и озбиљних напада који демантују тврдњу да „,агитпроповски жреци” овај есеј нису ни приметили (Џаџић 1996: 182). Део објављене грађе са састанака Партијске организације у Удружењу књижевника Србије открио је једног од најгласнијих Кашанинових опонената - Михаила Лалића. За писца Лелејске горе, као и, претходно, за Радована Зоговића, Кашанин је био - квислинг. Лалић

Кашаниновим текстом. Један други, стасити књижевни радник старије генерације чије име нећу поменути окомио се на Финција. То може да пусти само један Финци! [...] А професор граматике и писац уџбеника, познати угледни медиокритет и академик који никада не пропушта прилику да у јавним иступима одапне по коју отровну стрелу пут Светић-Хаџића и сличних [...] изван себе од беса купио је потписе за протестно писмо које би најугледнији требало да проследе 'Политици'. Текст је насловио Напад из бусије, а прва реченица је гласила: 'Из салонске бусије, опет су припуцали на Вука'. Писмо се, међутим, никада није појавило у 'Политици"” (Џаџић 1996: 183).

3 Зоран Глушчевић је оштар када пише о Гавелином читању Кашаниновог есеја: „[...] Ђура Гавела, подмлађени архаични културобрижник, хитар ко запета пушка у одбрану фолклорног 'народног тла'. На страну његова искривљена и тенденциозна интерпретација Кашаниновог текста из 'Књижевности' [...] али овај бескомпромисни борац за 'домаћу' културу иако на некултуран начин, спретно и са завидном вештином рукујући вулгарном методом квазимарксистичке праксе злонамерног сумњичења и извртања, у својој срдитој зловољи није ништа друго у стању да учини до да избегне полемику, јер још није 'озбиљно забринут за Вука', али зато способан за парафразу самог себе, за дуплу-експозицију, сопствене литерарне ненедахнутости" (Глушчевић 1953: 3).

${ }^{4}$ Глушчевић је детаљно писао о утицају немачког рококоа на Бранка, народној поезији, родољубљу и тако успео да афирмише ставове изречене у Кашаниновом есеју.

${ }_{5}^{5}$ Овај рад Зорана Глушчевића није забележен у литератури о Кашанину (Удовички 1982: 297-305). Морамо да напоменемо да Глушчевићев став о Кашанину није био апологетски. У приказу књиге Пронађене ствари, у којој је прештампан и есеј о Бранку, Зоран Глушчевић је већ самим насловом - „Писац једног изванредног есеја” - издвојио Кашаниново писање о Бранку (Глушчевић 1962: 3). Са друге стране, приказ није у целини афирмативан.

${ }^{6}$ Драгиша Живковић је и доцније у студијама „Трохеј или јамб Бранка Радичевића” и „Лирске врсте у песмама Бранка Радичевића” указао на различите оријентације у Радичевићевом певању, и даље одлучно негиравши поједине Кашанинове ставове. 
је жестоко замерао Финцију што је есеј штампао у часопису Књижевност, сматрајући да је потребно одбранити Вука Караџића и црногорски народ (sic!) од Кашанина (Матејић 2005: 64). Ту одбрану, што Вука, што црногорског народа, Лалић је, борећи се за сопствене позиције, осећао као своју мисију. $^{7}$

На усмене и писане нападе због есеја о Бранку у којима су се у исти кош стављали Југославија, Бранко, Вук и црногорски народ, одмерени Кашанин је ћутао. Ћутао је и када се петнаест година након објављивања есеја „Између орла и вука", у Политици поводом књиге Судбине и људи огласио Ели Финци - човек који је његов повратнички есеј смело прихватио за штампу у београдској Кюижевности. ${ }^{8}$ Критикујући пишчеву „борбену и агресивну есејистику” и „борбени конзерватизам”, Финци није био без утицаја на потоње тумаче. Замерајући Кашанину негацију свих напредних, револуционарних и прогресивних струја XIX и почетка XX века, отворено изјашњавање против свега што је плебејско, народско и сиротињско, а фаворизовање онога што одише духовним господством, издвојеношћу и аристократизмом, Финци је мало у алузијама, мало директно на неколико места поменуо и есеј о Бранку (1968: 18). Могућно је да су Финцијеве примедбе упућене на рачун Кашаниновог односа према ономе што су били постулати и идеје тадашњег поратног времена, подстакле појединце да измаком XX века закључе да је Кашанинов есеј бременит политичким алузијама (Ђурђевић 1997: 44). Оваква тумачења могла су да пронађу извориште и у сећањима Ериха Коша. У својим сећањима Кош је алудирао на Кашаниново „господство” и држање „осим света” што је представљало трн у оку тадашње књижевне врхушке (1990: 195). Брзо се он, по писању Ериха Коша, трансформисао у „самосвесног и ауторитативног господина конзервативне оријентације" и почео да објављује приповетке и есеје „међу њима и један о Његошу и Вуку, чији је садржај изазвао критичку реакцију Михаила Лалића због политичких порука које је садржавао" (Исто: 196). Лако је уочљива површност приликом преименовања есеја о Бранку Радичевићу у есеј о Његошу и Вуку. Главни јунак Кашаниновог есеја, Бранко Радичевић, заједно са својим песничким делом, био је заклоњен сенкама двојице горостаса српске књижевности, Његоша и Вука, сугерисано је насловом, а потврђено, нехотице, у сећањима Ериха Коша, који је и сам имао запажену улогу у хајки на Милана Кашанина (Димитријевић 2015: 68). Такође, чини се да је Кош прећутно одобрио бурну реакцију Михаила Лалића и тим чином само подгрејао тврдњу о политичким алузијама овога есеја. Међутим, настојање да се у сваком ретку пронађе алузија или симболика еквивалентна актуелном тренутку доприносила је само поједностављавању и банализовању написаног.

7 Лалић је овако нападао Кашанина: „Ја знам да је Кашанин квислинг, а ја не волим квислинге. [...] он не може да пише своје квислиншке и отровне подвале које он никада не би објавио у бившој Југославији, јер је ту бившу Југославију ипак волео и није хтео да разбија народно јединство у њој и да псује српски народ и његовог Вука, нити да псује црногорски народ” (Матејић 2005: 84).

${ }^{8}$ Кашанинов биограф, Радован Поповић, наводи да је есеј „Између орла и вука” првобитно био понуђен Летопису Матице српске (2016: 131). 
Било како било, бурну и не само књижевноисторијски већ и културолошки интересантну причу о рецепцији есеја „Између орла и вука”, са акцентом на оштре, личне и недовољно аргументоване критике не умањује ни чињеница да су временом уследиле похвале и бројни гласови уважавања. Ти гласови су се, међутим, изузев Глушчевићевог, највећим делом чули након појаве књига Пронађене ствари, односно Судбине и људи 1968. године. ${ }^{9}$

Избијање есеја о Бранку на сам почетак књиге Судбине и људи природно се наметнуо и због чињенице да поезија Бранка Радичевића стоји на почетку развоја модерне српске лирике. Коначно, утицајна и читана Антологија новије српске лирике Богдана Поповића која је обележила стасавање Кашаниновог нараштаја, започиње Бранковим стиховима. Кашанин је и сам неколико пута истицао да су у младости на њега велики утицај имали Јован Скерлић и Богдан Поповић, што га није омело да доцније испише прилично оштре судове о њима. Одјеци неслагања са Скерлићевим писањем о Бранку Радичевићу видљиви су, на пример, и у есеју „Између орла и вука”. (Директне замерке писцу студије Омладина и њена књижевност поводом читања Бранкове поезије Кашанин је изнео на другом месту.) Уосталом, познато је да Јован Скерлић није много држао до поезије Бранка Радичевића, сматрајући њен значај прецењеним и налазећи у његовом опусу превагу лоших над добрим стиховима. Скерлићевом укусу није годила Бранкова „груба сенсуалност” и вулгарност у љубавној лирици, а „Ђачки растанак” читао је само као „опис једне ђачке пијанке, једне доста грубе баханалије испод Магарчева Брда, где има много експанзивне joie de vivre, али исто тако и грубости и вулгарности" (Скерлић 1906: 431). Но, погрешно би било тврдити да је Кашанинова намера у овом случају била обрачун са давно мртвим Скерлићем. Заправо, пре се може закључити да је једна од намера Кашаниновог огледа о Бранку заоштравање и подвлачење у књижевној историји већ наговештених ставова о песнику „Туге и опомене”. У свом тумачењу поезије Бранка Радичевића Кашанин се користио и већ познатим књижевноисторијским судовима вешто их надограђујући смелим и иновативним тумачењима. Захваљујући оваквој синтези, написао је есеј незаобилазан за проучаваоце Радичевићевог дела.

Тражећи изворишта Кашаниновог есеја најпре ћемо се окренути промишљању односа „старог злодјеја” и Бранка Радичевића. Када је почетком $\mathrm{XX}$ века почело преиспитивање негативних страна Вукове реформе, Павле Поповић се, дискретно, 1911. године упитао: „Да није било Вука, ко зна какво би било певање Бранково? Да не и боље?” (Поповић: 1999: 119). Но, Кашанину се учинило интересантнијим резоновање једног, по истоветној упитаности, Поповићевог заборављеног претходника - Ђорђа Малетића. У многим фрагментима есеја „Између орла и вука” може се запазити Кашанинова рехабилитација Малетићеве критике прве збирке Бранкових песама. У есеју „Између орла и вука” овај заборављени критичар је, истина узгредно, и поменут уз констатацију да је од „свих савета и мишљења, најпаметније

\footnotetext{
9 Због ограничености простора донет је само кратак преглед рецепције есеја „Између орла и вука" након његовог изласка из штампе. Не би требало пренебрегнути чињеницу да је овај есеј имао и другачији вид рецепције, и да је она била бројнија и аргументованија.
} 
што је Радичевић чуо, то што му је рекао Ђорђе Малетић: 'Врати се натраг у своје гајеве"”. Одлика Малетићеве критике била је што је одлучно одбацио став филолошке критике да ваља „сваку нову књигу само по језику ценити” и први наслутио да Бранку близина Вука Караџића неће бити од велике користи у даљем певању:

Одкако се, по несрећи, с г. Вуком упознао, омрази се са својом небесном посестримом, презре оне лепе гајеве у којима га је посестрима песмама учила, прође се оне лепе забаве у певању и надпевању с птицама, а посвети се новом олтару око кога су жреци толику вику подигли (Малетић 1979: 453).

На Бранкову оданост Вуку оличену у поеми „Пут”, Малетић је гледао са негодовањем: „Бежи, дакле, из тог круга који ти је чело наборао, срце скаменио, ум занео, а крила укочио" (1979: 454). Сличне тезе проналазимо и у есеју Милана Кашанина који као најбоље Бранкове песме издваја управо оне написане од 1843. до 1847, за време његовог првог бављења у Бечу. Потребно је, најзад, још једну ствар подвући и разјаснити - исходиште Малетићевог размишљања не може се тражити у негативном односу према Вуковој реформи. Ђорђе Малетић, и сам песник, једноставно је осетио у ком смеру би требало да се развија даље песничко формирање младога Бранка. Није стога за чуђење што је први критичар есеја „Између орла и вука", Ђуро Гавела, Кашаниново перо ставио уз Малетићево.

Са друге стране, у Гавелиној критици наилазимо и на благе призвуке ироније који се односе на места у којима Кашанин говори о утицају Тодора Радичевића (Гавела 1979: 142). Гавели је, наравно, било јасно да би оспоравање утицаја Тодора Радичевића и његове библиотеке на песничко стасавање даровитог Бранка било врло неутемељено. Тим пре што је личност Тодора Радичевића значајно осветљена у периоду пре Првог светског рата захваљујући проучавању и прегнућу Љубомира Лотића, Павла Поповића и, касније, Теодоре Петровић, који су донели непознате биографске и библиографске податке о овом царинском чиновнику, преводиоцу, писцу, пренумеранту... Међутим, тек Кашаниново конфронтирање утицаја Тодора Радичевића насупрот Вуковом имало је ефекта:

Отац Бранков! Један мали цариник, који се селио из места у место са својом великом библиотеком и два мала сина, сиромашан, али поносит господин, у коме није било ничег од малограђанског ћифте, ни од сељака, ни од брђанског пастира - тај аутентични племић по склоностима, који је боље познавао светску поезију него 'отац српске књижевности' Вук... (Кашанин 1953: 368).

Тодор Радичевић, преводилац Шилера, несрећни отац који је сахранио своју децу, добио је значајно место у Кашаниновом есеју јер је несумњиво да је овај књигољубац и пренумерант, писац неколико басни, стихова у славу Доситеја Обрадовића и једне кратке драмске скице, имао удела и у Бранковом интересовању за књижевност. Уосталом, није ли му син слао написане стихове и чекао његов суд? Било је, дакако, примера резервисаности и ограђивања појединих истраживача када је реч о евентуалном утицају породичне библиотеке на Бранка Радичевића, али зашто оспоравати утицај оца и 
очеве библиотеке код Бранка Радичевића а прихватати га код неких других песника, на пример Војислава Илића? Нарочито када је познат и делимични списак књига из породичне библиотеке Радичевића које је Бранков отац оставио као легат гимназији у Карловцима.

Неспорно је да Кашанину није промакла ни једна важна студија посвећена Бранку Радичевићу. У позадини појединих размишљања Милана Кашанина може се назрети богато читалачко искуство и добро познавање ставова изнетих у студијама и текстовима његових претходника, да поменемо само Тихомира Остојића, Васу Стајића и Милана Шевића. Захваљујући, на пример, Остојићевим и Стајићевим увидима у рукописе Бранка Радичевића, Кашанин га неће доживљавати као импровизатора, већ као песника који промишља сваки написан стих. Свакако ће му бити корисни и подаци које је Шевић изнео у студији „О Бранковој смрти” конфротирајући различита писања и сведочења о последњим тренуцима Бранковим, вешто указујући на занесено и не у свему поуздано сећање Мине Караџић (Шевић 1925: 3-16). Подаци базирани на документу нису за Кашанина били безначајни, већ су му давали маха за смеле тезе којима је успео да уздрма и тргне читаоце. Најзад, постоје и проблематични делови овог есеја који се огледају се у Кашаниновом одбацивању утицаја народне књижевности на Бранка - неодрживе тезе након темељитих увида Драгише Живковића (1997: 7-111) и Марије Клеут (1973: 31-76). Такође, није једнодушно прихваћен став да Бранково песништво није створено у духу романтизма, те да се његова изворишта могу потражити најпре у традицији рококо лиричара (Удовички 1982: 50-51).

Кашанинов приступ у есеју „Између орла и вука” има несумњива упоришта у проучавању његових претходника. Давно постављене и наслућене тезе Кашанин је оденуо у ново рухо и без околишења сасуо у лице читалачке публике. Његови редови о Бранку израз су смирене и сигурне руке књижевног историчара и посматрача, свесног да се у преиспитивању и ревалоризовању окошталих ставова мора померити тло под ногама да би се ствари изокренуле и поставиле на своје место. Ређање бројних парадокса и заоштравања већ познатих ставова, донели су есеју „Између орла и вука” свежину и утисак новине. И данас овај истовремено и куђен и хваљен есеј, иако објављен пре више од шест деценија, не оставља места за равнодушност и привлачи неподељену пажњу како због мајсторског начина презентације чињеница тако и због сјајног и заводљивог стила којим је написан. Своје тезе Кашанин је изнео без увијања и кађења тамјаном, али и са потребном мером. Реченица његових есеја је и данас заводљива, а велики број изнетих теза одржив. Стога није ни чудо што поједини наши савременици, очигледно заведени Кашаниновим ставовима, не могу да одоле а да у свој текст не унесу и редове из његових есеја. Спорно је само то што их потписују као своје. ${ }^{10}$

${ }^{10}$ Један овакав пример присвајања разоткрио је Миливој Ненин у предговору Књиге о Змају Лазе Костића: „Управо тај пасус [из Кашаниновог есеја о Лази Костићу] преузеће и Немања Ротар, парафразирајући га - на опасној ивици цитата - једино заборављајући да помене Кашанина" (Ненин 2013: 21). 


\section{ЛИТЕРАТУРА}

Гавела1979: Ђ. Гавела, Огледи и критике, Београд: Српска књижевна задруга. Глушчевић 1953: 3. Глушчевић, Проблем оригиналног и национални патос (Између орла и вука), Уметност и критика, I/2, 1-[3-4].

Глушчевић 1962: З. Глушчевић, Писац једног изванредног есеја. Милан Кашанин, Пронађене ствари, Кьижевне новине, XIV, 167, 3.

Димитријевић 2015: К. Димитријевић, Разговори са Миланом Каманином, Београд: Catena mundi.

Ђурђевић 1997: М. Ђурђевић, Последњи Вуков противник из пречанске учене класе, Улазница, XXXI, 153, 26-45.

Живковић 1957: Д. Живковић, Почеци српске књижевне критике (18171860), Београд: Рад.

Живковић 1997: Д. Живковић, Европски оквири српске књижевности III, Београд: Просвета.

Кашанин 1953: М. Кашанин, Између орла и вука, Књижевност, VIII/XVII, 365-381.

Клеут 1973: М. Клеут, Бранко Радичевић и народна књижевност, Зборник за славистику, 5, 31-77.

Ковачек 2005: Б. Ковачек, Милан Кашанин и Матица српска, Летопис Матиие српске, 181/ 476/5, 929-937.

Кош 1990: Е. Кош, Одломии сећања, писии, Београд-Будва-Нови Сад: Просвета-Медитеран-Матица српска.

Малетић 1979: Ђ. Малетић, Песме Бранка Радичевића, Почеии српске књижевне критике, (прир.) Ј. Деретић, Нови Сад-Београд: Матица српска-Институт за књижевност и уметност.

Матејић 2005: С. Матејић, Партијска организащија у Удружењу књижевника Србије: од 1954-1960 године у фонду Градског комитета, Шабац: Заслон.

Ненин 2013: М. Ненин, Чиста књига или Костићева одбрана поезије, Лаза Костић, Кюига о Змају, Нови Сад: Матица српска.

Поповић 1999: П. Поповић, Нова књижевност II, (прир.) П. Палавестра, Београд: Завод за уџбенике и наставна средства.

Поповић 2016: Р. Поповић, Аристократ духа. Животопис Милана Кашанина, Нови Сад: Матица српска.

Удовички 1982: И. Удовички, Књижевни критичар Милан Кашанин, Београд: Институт за књижевност и уметност-Вук Караџић.

Финци 1968: Е. Финци, Борбени конзервативизам. Уз књигу Милана Кашанина, Судбине и људи, Политика, 15. XII 1968, 18.

Џаџић 1996: П. Џаџић, Из дана у дан III, Београд: Завод за уџбенике и наставна средства.

Шевић 1925: М. Шевић, О Бранковој смрти, Нови Сад: Д. Д. „Натошевић”. 
Zorica P. Hadžić

\section{"BETWEEN THE EAGLE AND THE WOLF" - KAŠANIN ABOUT BRANKO RADIČEVIĆ}

\section{(Summary)}

Essay about Branko Radičević, published in 1953, "returned” Milan Kašanin to Serbian literature. Kašanin writings on Branko Radičević attracted attention immediately; its value estimations were highly divided - from pamphlet and malicious criticism from Đuro Gavela, through insufficiently appreciated defens of his writing by Zoran Gluščević, up to these interpreters who in this essay noted the bitter criticism of post-war conditions. In this research, we discuss the general reception of the essay and its non-literature background in parallel with possible origination of Milan Kašanin ideas in interpretation of Branko Radičević poetry and his life circumstances. 